Original Research Article

\title{
A prospective study to evaluate oral iron preparations in antenatal women at a tertiary care hospital
}

\author{
Satyanarayana V.*, Shabeer D., Suma Jayaram, Basavaraj Bhandare
}

Department of Pharmacology, Rajarajeswari Medical College and Hospital, Bangalore, Karnataka, India

Received: 17 January 2017 Accepted: 25 February 2017

\section{*Correspondence to:}

Dr. Satyanarayana V.,

Email:

Satyanarayana72@yahoo.co.in

Copyright: (C) the author(s), publisher and licensee Medip Academy. This is an openaccess article distributed under the terms of the Creative Commons Attribution NonCommercial License, which permits unrestricted noncommercial use, distribution, and reproduction in any medium, provided the original work is properly cited.

\begin{abstract}
Background: Iron deficiency is the most common cause of anemia in pregnancy worldwide. It can be mild, moderate or severe. Severe anemia can have very serious consequences for mothers and babies. Pregnant women requiring medication represent a challenge to healthcare providers to avoid any teratogenic risk to foetus. The purpose of this study was to provide information about the most effective iron preparations prescribed to pregnant women and to evaluate the haemoglobin status before and after oral iron therapy.

Methods: This was a Prospective observational study conducted in the Department of Obstetrics and Gynaecology, Rajarajeswari Medical College and Hospital, between October 2013 and March 2014.This study was conducted by reviewing the antenatal care Outpatient department case papers of 200 pregnant women who were anaemic.

Results: Demographic profile, detailed medical history and drug intake in current pregnancy was noted. The prescription pattern was assessed. Of the three common iron preparations prescribed, Ferrous sulphate was the most common preparation. Findings of our study showed that all pregnant anaemic women included in the study were provided with iron and folic acid therapy and the most effective oral iron preparation was Ferrous sulphate.

Conclusions: Present study shows that ferrous sulphate is the most common iron preparation prescribed. Ferrous sulphate and ferrous fumarate preparations showed better improvement in $\mathrm{Hb}$ levels. Anaemia is common among all pregnant women and therefore it raises the concern about high morbidity and mortality associated with pregnancy outcome. This can be minimized by educating pregnant women about importance of balanced diet and utilization of antenatal facilities even during early pregnancy.
\end{abstract}

Keywords: Drug utilizalion, Ferrous-sulphate, Iron preparations, Pregnant women

\section{INTRODUCTION}

Iron deficiency anaemia is the most common nutritional deficiency in the world. Anaemia is defined by World Health Organization as a state where haemoglobin $(\mathrm{Hb})$ is less than $11 \mathrm{gm} / \mathrm{dl}$ and haematocrit less than $33 \%$. $^{1}$ Estimates from the WHO report that $35-75 \%$ (average $56 \%$ ) of pregnant women in developing countries and $18 \%$ of women from industrialized countries are anaemic. The most common cause of anaemia is iron and folate deficiency. Iron deficiency anaemia accounts for $75-95 \%$ cases of anaemia in pregnancy. It can occur because of poor nutrition, malaria, hookworm infestation and closely spaced pregnancies.
The net Iron requirements for pregnancy is $840 \mathrm{mg}$ approximately. $^{2}$ Per WHO Daily oral iron and folic acid supplementation with $30 \mathrm{mg}$ to $60 \mathrm{mg}$ of elemental iron is recommended for pregnant women to prevent maternal anaemia, puerperal sepsis, low birth weight, and preterm birth. $^{3}$

Pregnant women commonly develop iron deficiency anaemia because of increasing iron demand of the developing foetus and placenta and the increased blood circulating volume in the body during pregnancy. ${ }^{4}$ In pregnancy, the total volume of plasma is dramatically increased $(50 \%)$ along with increase in red cell mass (18$25 \%)$, because of this disproportionate increase in plasma 
volume, there is physiological heamo dilution and the haemoglobin is consequently reduced to a varying extent, making anaemia the most common haematological abnormality diagnosed during pregnancy. ${ }^{5}$ Iron requirement increases notably during the second half of pregnancy because of the expansion of the red blood cell mass and the transfer of increasing amount of iron to both the growing foetus and the placental structures. ${ }^{2}$ Iron deficiency in pregnant therefore limits oxygen delivery to cell resulting in fatigue, poor work performance and decreased immunity. ${ }^{2}$ Iron deficiency anaemia may be associated with detrimental effects on maternal and infant function. Anaemia results in an increased number of preterm deliveries, low birth weight, impaired cognitive development of children, postpartum haemorrhage, postpartum depression. $^{2}$ Diet alone cannot supply such amounts of iron in non-industrialised countries making iron supplementation a necessity in all pregnant women. ${ }^{6}$ Iron can be supplemented by oral route, intramuscular or intravenous injection. Alternatively, blood transfusion and recombinant erythropoietin are used.

The choice of treatment in iron deficiency anemia is oral iron replacement because it is safest and least expensive. The equivalent of $60 \mathrm{mg}$ of elemental iron is $300 \mathrm{mg}$ ferrous sulfate heptahydrate, $180 \mathrm{mg}$ ferrous fumarate or $500 \mathrm{mg}$ of ferrous gluconate. ${ }^{3}$ lntolerance to iron and non-compliance in some women may make oral iron therapy inadequate and these can he benefited from parenteral iron therapy. The traditional treatment by blood transfusion involve significant drawbacks. Therefore, intravenous iron alone or in association with recombinant human erythropoietin (rHvEPO) therapy has been considered as an alternative in the management of iron deficiency in this setting. ${ }^{7}$

Major disadvantages are cost, need for hospitalization or an out-patient setting and invasive nature of procedure. Presently drug utilization studies are in an evolving era. Their scope is to evaluate the present practices in prescribing of drugs and adherence to evidence based recommendations. ${ }^{8}$ It therefore becomes vital to study the drug utilization pattern during pregnancy to estimate to what extent there may be a scope for improvement in the current prescribing pattern. ${ }^{9}$ Hence, present study was therefore conducted to evaluate the most effective oral iron supplementation on $\mathrm{Hb}$ levels and assessment of the prescription pattern in pregnant anemic patients.

\section{METHODS}

After obtaining approval from the Institutional ethical committee, a prospective open labelled observational study was conducted between October 2013 and March 2014. Data was collected from 200 outpatients attending the antenatal out Patient Department Gynaecology and Obstetrics of Rajarajeswari Medical College and Hospital, Bangalore, India. A pre-designed Proforma consisting of demographic data of pregnant women along with obstetric history and history of associated medical, surgical, gynaecological and obstetrical illness was documented in the OPD. The detailed information on the iron supplements, drug dose, dosage form, frequency, duration of treatment was recorded. The haemoglobin status at the $1^{\text {st }}\left(4^{\text {th }}\right.$ month $)$ and the $3^{\text {rd }}$ antenatal visit $\left(9^{\text {th }}\right.$ month) was recorded. Informed consent was obtained from all the study subjects after fully explaining the study procedure in both English and regional language. They were given a simple calendar to tick mark whenever they took their daily dose to record and maintain compliance. Subjects satisfying the inclusion criteria were recruited into the study. Pregnant women with $\mathrm{Hb} \%$ levels less than $11 \mathrm{~g} \mathrm{dl}$ were included in the study. Pregnant women having any allergy to iron, women with malabsorption syndrome, women with thalassemia and women diagnosed with acute and chronic medical conditions requiring hospitalization were excluded from the study. women with $\mathrm{Hb}$ level $<7 \mathrm{~g} / \mathrm{dl}$ were also excluded.

\section{Statistical analysis}

Results on continuous measurements are presented on Mean \pm SD and results on categorical measurements are presented in Number (\%). Significance is assessed at 5 \%level of significance. Student $t$ test has been used to find the significance of study parameters on continuous scale between two group. Chi-square/Fisher Exact test has been used to find the significance of study parameters on categorical scale. ANOVA test was used to assess the level of significance between the groups. $P$ value of $<0.05$ was considered significant. The results were also depicted in the form of tables and graphs where necessary. Microsoft Word and Excel are used to generate graphs and tables.

\section{RESULTS}

The demographic profile of the 200 pregnant women recruited in the study is depicted in Table 1.

Table 1: Demographic data of pregnant women attending OPD.

\begin{tabular}{|ll|}
\hline Demographic data & Results \\
\hline Age in years (mean \pm SD) & $23.65 \pm 5.07$ \\
\hline Literacy status, number $(\%)$ & \\
\hline Illiterate & $26(13.8)$ \\
\hline Primary education & $29(15.4)$ \\
\hline Secondary education & $122(64.8)$ \\
\hline Graduate & $11(5.8)$ \\
\hline Employment, number $(\boldsymbol{\%})$ & \\
\hline Unemployed & $165(87.7)$ \\
\hline Employed & $23(12.2)$ \\
\hline Gravida, number $(\boldsymbol{\%})$ & \\
\hline Primigravida & $103(51.5 \%)$ \\
\hline Second Gravida & $81(40.5 \%)$ \\
\hline Multigravida & $16(08 \%)$ \\
\hline
\end{tabular}


Average age of pregnant women was 23. $65 \pm 5.07$ years (Range 18 to 40 years). Age distribution coincides with pregnant women profile seen in literature. ${ }^{10}$ Majority of pregnant women Included in the study were housewives and only few (12.2\%) were working.

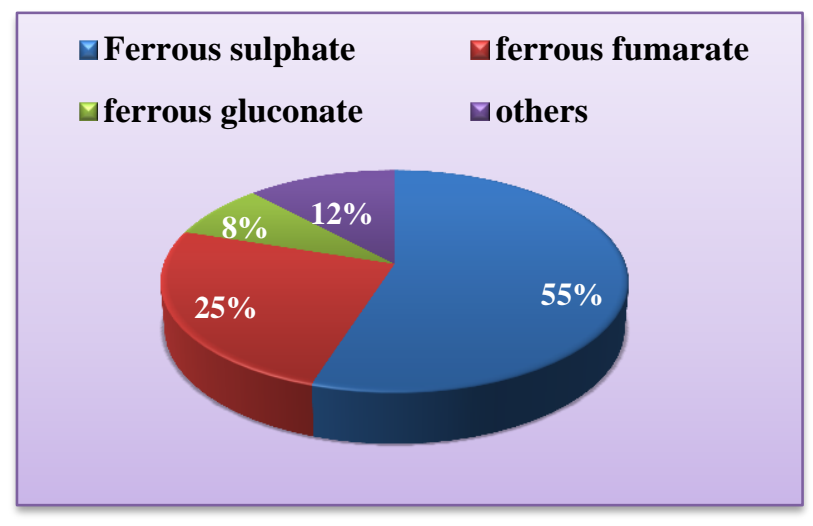

Figure 1: Percentage of different iron preparations prescribed at the OPD.

\section{Side effect profile}

In the ferrous sulphate treated group, 12 women complained gastric irritation; in the ferrous fumarate group 9 women complained of constipation but were not significant.

Table 2: Dose and elemental iron content per tablet of various oral iron preparations prescribed.

\begin{tabular}{|llll|}
\hline Iron salt & $\begin{array}{l}\text { Dose per } \\
\text { tablet }\end{array}$ & $\begin{array}{l}\text { Elemental } \\
\text { iron }\end{array}$ & $\begin{array}{l}\text { Total } \\
\text { elemental iron }\end{array}$ \\
\hline $\begin{array}{l}\text { Ferrous } \\
\text { Sulphate }\end{array}$ & $300 \mathrm{mg}$ & $60 \mathrm{mg}$ & $120 \mathrm{mg}$ \\
\hline $\begin{array}{l}\text { Ferrous } \\
\text { Fumarate }\end{array}$ & $200 \mathrm{mg}$ & $65 \mathrm{mg}$ & $130 \mathrm{mg}$ \\
\hline $\begin{array}{l}\text { Ferrous } \\
\text { Gluconate }\end{array}$ & $300 \mathrm{mg}$ & $35 \mathrm{mg}$ & $70 \mathrm{mg}$ \\
\hline
\end{tabular}

\section{DISCUSSION}

Iron deficiency anaemia in pregnancy is an important preventable cause of maternal and perinatal morbidity and mortality. According to WHO Iron deficiency anaemia in pregnant women is defined as $\mathrm{Hb}<11 \%$. A total amount of about $700-850 \mathrm{mg}$ of iron is needed to meet the iron requirements of a mother and foetus during pregnancy, at delivery and during the perinatal period. Iron requirement increases during the second half of the pregnancy and especially during the last trimester. This excess iron demand can be met either from mother's endogenous iron stores or from iron supplements. However, the mean iron content of the body reserves ferritin and hemosiderin is often only around 200250mg. ${ }^{11}$
Table 3: Mean hemoglobin concentration pre-and post-oral iron therapy.

\begin{tabular}{|llll|}
\hline & $\begin{array}{l}\text { Mean HB } \\
(\mathrm{gm} / \mathbf{d l}) \\
\text { mean } \pm \text { SD }\end{array}$ & $\begin{array}{l}\text { Mean HB } \\
(\mathrm{gm} / \mathbf{d l}) \\
\text { mean } \pm \text { SD }\end{array}$ & $\begin{array}{l}\text { Improvement } \\
\%\end{array}$ \\
\hline $\begin{array}{l}\text { Ferrous } \\
\text { sulphate }\end{array}$ & $8.2 \pm 0.79$ & $12.4 \pm 0.79$ & 45.5 \\
\hline $\begin{array}{l}\text { Ferrous } \\
\text { fumarate }\end{array}$ & $8.3 \pm 0.69$ & $12.2 \pm .36$ & 42.2 \\
\hline $\begin{array}{l}\text { Ferrous } \\
\text { gluconate }\end{array}$ & $8.2 \pm 0.69$ & $10.2 \pm .49$ & 22.5 \\
\hline & $1^{\text {st }}$ visit was at $4^{\text {th }}$ month of pregnancy/first antenatal check up; \\
${ }^{* * *} 2^{\text {nd }}$ visit was at ${ }^{\text {th }}$ month of pregnancy/ third antenatal check \\
up
\end{tabular}

up

Physicians often face poor compliance among mothers in daily practice with oral therapy because of digestive side effects which can lead to worsening of anaemia. In these cases, parenteral forms of administration are indicated as well as in those patients in whom oral treatment is ineffective. like in those suffering from inflammatory bowel disease, many of whom are iron deficient and show digestive intolerance to ferrous salt. ${ }^{12,13}$

Table 4: Comparison between the groups for statistical difference in the outcome of treatment.

\begin{tabular}{|lll|}
\hline Groups & p value & Remarks \\
\hline $\begin{array}{l}\text { Ferrous sulphate vs } \\
\text { ferrous fumarate }\end{array}$ & 0.27 & $\begin{array}{l}\text { No significant } \\
\text { difference seen }\end{array}$ \\
\hline $\begin{array}{l}\text { Ferrous sulphate vs } \\
\text { ferrous gluconate }\end{array}$ & 0.027 & $\begin{array}{l}\text { Significant } \\
\text { difference seen }\end{array}$ \\
\hline $\begin{array}{l}\text { Ferrous fumarate vs } \\
\text { ferrous gluconate }\end{array}$ & 0.031 & $\begin{array}{l}\text { Significant } \\
\text { difference seen }\end{array}$ \\
\hline
\end{tabular}

Average age of pregnant women was 23.6 \pm 5.07 years (Range 18 to 40 years). Majority of pregnant women were housewives and only few (12.2\%) were working. Approximately half of the women were primigravida $(51.5 \%) .40 .5 \%$ of women were second gravida and only $8 \%$ of women were multigravida. In the present study, three oral iron formulations were prescribed to antenatal women with ferrous sulphate being the most common preparation. Ferrous sulphate was prescribed to 110 (55\%) patients and has an elemental iron of $60 \mathrm{mg}$. Ferrous Fumarate was prescribed to 50 (25\%) patients and has an elemental iron of $65 \mathrm{mg}$. Ferrous Gluconate was prescribed to $16(8 \%)$ patients and has an elemental iron of $35 \mathrm{mg}$.

In this study, the baseline $\mathrm{Hb}$ level of patients who were prescribed with ferrous sulphate, ferrous fumarate and ferrous gluconate was $8.2 \mathrm{~g} / \mathrm{dl}, 8.3 \mathrm{~g} / \mathrm{dl}$, and $8.2 \mathrm{~g} / \mathrm{dl}$ respectively.

The Hb level of post oral iron therapy of ferrous sulphate treated group, ferrous fumarate treated group and ferrous gluconate treated group was $12.4 \mathrm{~g} / \mathrm{dl}, 12.2 \mathrm{~g} / \mathrm{dl}$ and $10.2 \mathrm{~g} / \mathrm{dl}$ respectively. Following the third visit of patients 
in the last trimester the percentage improvement in $\mathrm{Hb}$ level of patients treated with ferrous sulphate was $45.5 \%$ and ferrous fumarate was $42.2 \%$ (Table 3 ).

Similar results in a study conducted by Lekha Saha et al. showed a significant increase in $\mathrm{Hb}$ level, the increase in $\mathrm{Hb}$ concentration after treatment was statistically significant when compared to the baseline value. ${ }^{14}$ Oral iron supplementation is the treatment of choice in iron deficiency anaemia in pregnancy and almost all women can be treated effectively with oral preparations. ${ }^{13}$

\section{Limitation}

The study has been done in a small population with restricted study period. The improvement of anaemia could have included other iron parameters like serum Ferritin levels; estimation of TIBC.

\section{CONCLUSION}

Findings of our study showed that all eligible pregnant women were provided with iron and folic acid therapy. Pregnant women with diseases like hypertension, epilepsy and diabetes were continued with the appropriate drugs considering the risk benefit ratio. Data analyzed from our study shows that ferrous sulphate is the most common iron preparation prescribed which is in accordance with other studies.

Ferrous sulphate and ferrous fumarate preparations showed better improvement in $\mathrm{Hb}$ levels in comparison to ferrous gluconate which was statistically significant. Anaemia is common among all pregnant women and therefore it raises the concern about high morbidity and mortality associated with pregnancy outcome. This can be minimized by educating pregnant women about importance of balanced diet and utilization of antenatal facilities even during early pregnancy.

Funding: No funding sources

Conflict of interest: None declared

Ethical approval: The study was approved by the Institutional Ethics Committee

\section{REFERENCES}

1. World Health Organization. Prevention and management of severe anemia in pregnancy. Report of a Technical Working Group, Geneva. 20-22 May 1991. Maternal health and safe motherhood programme, Geneva: WHO; 1993.

2. Hallberg L. Iron balance in pregnancy and lactation. In: Fomon SJ. Zlotkin S. (Eds). Nutritional anemias, New York: Raven Press; 1992:13-25.
3. World Health Organization. Daily iron and folic acid supplementation during pregnancy. Available from:http://www.who.int/elena/titles/guidance_summ aries/daily_iron_pregnancy/en/. As accessed on 14/04/14.

4. Auerbach M, Goodnough LT, Picard D, Maniatis A. The role of intravenous iron in anemia management and transfusion avoidance. Transfusion. 2008;48:988-1000.

5. Letsky EA. Anemia. In: James DK, Steer PJ, Weiner CP. Gonik B. editors. High risk pregnancy management options. 2nd ed. London: WB Saunders; I999:729-47.

6. Levine H, Pollit E, Galloway R, Mcguire J. Micronutrients deficiency disorders. In: Jamison D. Mosley H. Mesham A, Bobdilla JL. (Eds). Disease control priorities in developing countries. New York: Oxford University press; 1993:1042.

7. World Health Organization. Report of a WHO Group of Experts on Nutritional Anemias, Technical Report Series No. 503, Geneva WHO; 1972.

8. Gama H. Drug utilization studies. Arquivos De Medicina. 2008;22(2/3):69-74.

9. De Jong LT, Van den Berg PB, Peters PW, HaaijerRuskamp FM. A study of drug utilization during pregnancy in the light of known risks. Int J Risk Saf Med. 1990;1(2):91-105.

10. Mitchell AA1, Gilboa SM, Werler MM, Kelley KE, Louik C, Hernández-Díaz S. Medication use during pregnancy, with particular focus on prescription drugs: 1976-2008. Am J Obstet Gynecol. 2011;205(1):51.e1-8.

11. Chanarin I, Rotman D. Further observations on the relation between iron and folate status in pregnancy. British Med J. 1971;2:81-4.

12. Satyanarayana P, Manaswi C, Kalyani P. Oral iron therapy in anaemic and non anaemic pregnant women. Int J Scientific Res Publications. 2014;4(3).

13. Osungbade KO, Oladunjoye AO. Preventive treatments of iron deficiency anaemia in pregnancy: a review of their effectiveness and implications for health system strengthening. J pregnancy. 2012;2012.

14. Saha L, Pandhi P, Gopalan S, Malhotra S, Saha P. Comparison of efficacy, tolerability, and cost of iron polymaltose complex with ferrous sulphate in the treatment of iron deficiency anemia in pregnant women. Med Gen Med. 2007;9(1):1.

Cite this article as: Satyanarayana V, Shabeer D, Jayaram S, Bhandare B. A prospective study to evaluate oral iron preparations in antenatal women at a tertiary care hospital. Int J Basic Clin Pharmacol 2017;6:851-4. 